\title{
The Criminals in Vilnius
}

\section{Agnieszka Wójtowicz}

Institute of Linguistics at the University of Opole, 45-040 Opole, pl. Kopernika 11a

Email:agklimek@gmail.com

Repertuar stary nie bawi w Wilnie już, nowy repertuar nie bawi go jeszcze (The old repertoire does not entertain in Vilnius anymore; the new repertoire still does not entertain there $)^{1}$

\begin{abstract}
On 29 April 1930, the premiere of Ferdinand Bruckner's The Criminals (original title Die Verbrecher) directed by Aleksander Zelwerowicz took place at the Teatr Wielki na Pohulance in Vilnius. After two performances, the play was cancelled by the mayor of Vilnius. The authorities of the city were outraged by the 'drastic amoral scenes (homosexual love, abortion)'. Zelwerowicz submitted his resignation, which he withdrew a few days later. A performance combined with a debate on the drama was organised. One of the Literary Wednesdays was also devoted to a discussion about The Criminals. The Stowo daily published an open letter to the director Zelwerowicz 'supporting his repertoire policy'. Eventually, The Criminals was cancelled. Based on the unique documents I have found, publications in the press, photographs, and reminiscences of the participants, I will try to reconstruct these events and, above all, to describe and reinterpret the performance that was to introduce the cultural Vilnius to the truly modern and European track'
\end{abstract}

KEYWORDS: Grand Theatre in Pohulanka Street, Vilnius, Ferdinand Bruckner, The Criminals, Aleksander Zelwerowicz, scandal, censorship, Paweł Jasienica

\section{PROLOGUE: BEFORE AND DURING THE GREAT WAR}

It must be stated from the very beginning that Polish Vilnius was not a theatre city. The history of the Polish stage in Vilnius from around 1863 until the end of the Great War is actually a long series of failures. Theatre directors of Vilnius 'proved powerless in the face of the unheard-of difficulties of managing a theatre in Vilnius.'

The inhabitants of Vilnius were an ungrateful audience and the efforts to convince the 'locals' to go to the theatre were usually unsuccessful. This was undoubtedly a result of repressions after the January Uprising (including the ban on using the Polish language), the repercussions of which theatre experienced throughout the interwar period. It is worth mentioning, however, that Polish theatre in Vilnius was closed down a year before the January Uprising due to poor audience attendance.

1 W. Baranowski, 'Teatr wileński', Kurier Litewski, 27 April (10 May) 1914, No. 89.

2 Kurier Litewski, 1915, No. 112. 
The history of Polish theatre in Vilnius restarted in 1906 under the management of Nuna Młodziejowska. The theatre rose from the lowest possible level, that of non-existence.

Młodziejowska founded the first permanent Polish theatre in the Taken Lands in over forty years and managed to elevate it to a level that could compete with the best theatres in the country. However, it was too much for Vilnius and Młodziejowska had to lose. ${ }^{3}$

Benedykt Hertz claimed that the reason for Młodziejowska's resignation from managing the theatre was not so much insufficient funding as discouragement: she did not have the support of the public.

The landed gentry would go to the theatre as if for a social rendezvous, the intelligentsia would make various demands on art while lacking artistic competence, and the low-life was bound together more by Catholicism than by the Polish identity. ${ }^{4}$

The theatre in Vilnius was endowed with a didactic and patriotic mission greater than in any other place, while in the opinion of the critics it enjoyed special treatment. The audience demanded a 'state-of-the-art theatre', but it was not able to fill the auditorium. The theatre was most successful when it offered cheap tickets, which usually meant poor quality of the performances. The indifferent reaction of the residents of Vilnius towards a classical repertoire was tantamount to the material and aesthetic failure of a theatre production. As Dziennik Wileński stated in 1907, 'the Polish public supports everything: Russian theatre, poor Italian opera [...], illusions, cabarets, and only the Polish theatre is empty.'5

The works of Young Poland and by foreign authors were received inconsistently by audiences and critics. Reactions were usually moderate.

Baranowski, a journalist and the director of the theatre for some time during the 1911/1912 season, wrote that 'the theatre that serves art and culture must be really in deficit.' ${ }^{6}$ The great Romantic repertoire was popular, although Słowacki was received rather coldly.

Despite the critics' complaints, audiences attended farces and comedies: 'even laughter should enhance culture, and if it does not, it can easily become an element of stupefaction not only for the audience but also for the actors. ${ }^{7}$

The audiences of Vilnius primarily responded to historical art with a patriotic background, and this did not change in the interwar period. Hence the success of such dramas as Władysław Ludwik Anczyc’s Kościuszko pod Ractawicami (Kościuszko at Racławice) and Elżbieta Bośniacka’s Obrona Częstochow (The Battle of Częstochowa);

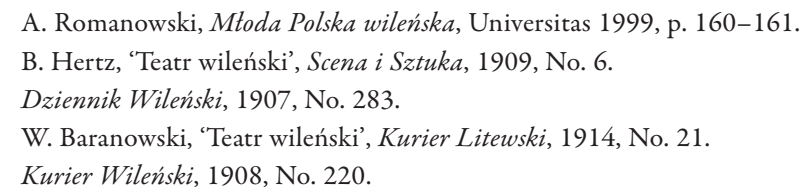


performances of guest stars also attracted a full auditorium. Baranowski accurately commented on the situation: 'The average Polish play and even the average foreign one is rarely successful as such on the Vilnius stage. The old repertoire does not entertain in Vilnius anymore; the new repertoire does not entertain there yet. ${ }^{3}$

Neither Warsaw nor Cracow nor Lviv were the appropriate background for Vilnius. The residents of Vilnius were an ungrateful audience: 'A Varsovian cannot exist without theatre, it is as necessary for them as bread: a citizen of Vilnius is accustomed to see theatre as an adventurous appetiser of everyday life, without which they can just do fine. [...] A powerful drama, which touches hearts all over the world, fails to affect anyone here. A fine comedy fails. The delicious farce arouses moralistic protests... Suddenly an old cliché play triumphs again!'

It is significant that attendance at the Vilnius theatre increased in the summer of 1915 due to the influx of refugees from the Congress Poland. Undoubtedly, in the first period after the forty-year break, the theatre in Vilnius often descended to the level of a provincial stage, but it is necessary to remember not only this beginning from scratch, but also the poorer artistic background than in the Congress Poland. The legacy of Młodziejowska's theatre was adopted in the interwar period by such projects as Osterwa's Reduta (the theatre group considered to be Poland's first theatre laboratory) or Aleksander Zelwerowicz's management, and they would face the same problems as in the pioneering period.

The year 1918 was undoubtedly a turning point for the Polish theatre, as theatrical life began to take shape in accordance with new, integrated principles. In the years of the formation of independent Poland (11 November 1918-24 March 1921), the life of the Vilnius stage was troubled by the ongoing warfare in the area and several changes of government. After 1921, the principles of operation of theatres changed; other than that, not much. During this first period, the theatre with the greatest popularity was Reduta's, which not only presented Vilnius with a repertoire of which Fircyk $w$ zalotach (The Dandy's Courtship) turned out to be the least important play, but also toured the towns of the Borderland (Pol., Kresy) with its best cast headed by Juliusz Osterwa.

Just before Reduta's arrival in Vilnius, Czesław Jankowski warned Osterwa:

The main reason for the decline of theatre in Vilnius is the too [...] small size of the permanent theatre audience. Simply put: there are not enough of them. The landed gentry, which constantly passed through Vilnius before the war and mainly supported the theatre, fell into a severe decline themselves, while the Polish clerical mass, now abundant in Vilnius, cannot afford the theatre; among the petty bourgeoisie and the artisans, the theatre audience has ceased to develop as it did before the war. We must also add the high cost of living in Vilnius [...] No repertoire can cope with this, even if performed and directed perfectly. The spiritual need for the theatre

8 Ibidem.

9 W. Baranowski, 'Teatr Wileński', Kurier Litewski 1914, No. 89. 
is decreasing. The hunger for theatre has almost completely ceased. [...] These are the major dilemmas with which Mr Osterwa's next-season party should reckon. ${ }^{10}$

Reduta set a benchmark too high for the average resident of Vilnius to grasp. When it came to Reduta's settling in Vilnius, the public opinion was confused. The art presented by Reduta was 'too simple and at the same time too great' in comparison with the well-known realistic repertoire. The reasons for Reduta's defeat in Vilnius were pointed out by the local press: 'a theatre which is too sublime for average tastes, which offers too few premieres and does not present its actors by name.'11

This is how the invaluable Czesław Jankowski characterised the situation of Vilnius theatres in 1927:

The tone of theatre life in Vilnius is set by Reduta [...] The Polish Theatre under the management of Franciszek Rychłowski is a seemingly autonomous branch of Reduta, was rather a satellite thereof. [...] While the Pohulanka stages plays almost exclusively from the so-called 'grand repertoire'. The Polish Theatre in Lutnia practises uniformly light comedy. Roles are divided. The audiences of Vilnius are offered a wide range of repertoire, from Wyzwolenie (The Liberation) to Pociag widmo (The Ghost Train). Both theatres work beyond any norm of theatrical audience, In Vilnius, despite a population of up to 200,000, the Polish theatrical audience is small. The Polish Theatre must offer novelties. It must keep up with two or three theatres in Warsaw. Vilnius wants to see what Warsaw found worth seeing. Therefore superhuman efforts are made in the Polish Theatre and in Reduta. Keeping up with the Warsaw repertoire, do the theatres in Vilnius have enough support ${ }^{12}$

Reduta's team struggled to survive in Vilnius until 1929, when the Union of Polish Stage Artists sent Aleksander Zelwerowicz and a group of students graduating from the Drama Department of Warsaw Conservatoir to take Reduta's place in Vilnius. Zelwerowicz organised a theatre more suited to public preferences than Reduta, which required a special atmosphere.

Zelwerowicz created an outstanding theatre, especially in his first season. However, he did not last long either, 'leaving behind a fine tradition, an audience as capricious and uncertain as ever in Vilnius, and, finally, a considerable debt to the theatre.' 13

Both Osterwa and Zelwerowicz were connected with the political establishment, which did not help them much in Vilnius.

12 Czesław Jankowski, Teatry wileńskie (text from 1927).

13 Marja Alexandrowicz, Dzieje teatru wileńskiego, Vilnius, 1938. 


\section{THE CITY OF PARADOX}

A more detailed examination of Vilnius leads to the sphere of paradox. Tomas Venclova sees a particular paradox in Vilnius being a capital and a border city simultaneously: 'whatever happens, Vilnius remains a borderland.' ${ }^{14}$

In the interwar period, Vilnius was a university city with good schools and a very active intelligentsia grouped around Witold Hulewicz, the Vilnius Broadcasting Company, and the Institute for Eastern European Studies. Czesław Miłosz wrote: 'The provinciality of Vilnius. It bothered me a lot and I longed to get out into the world. So there is no need to create a myth about the beloved and lost city if I could no longer stand it there [...]. Vilnius was in backwoods: an incredibly narrow base, if you count out the Jews who spoke and read Yiddish or Russian, and the mindless [locals]. What is left? Some intelligentsia of noble origin, generally quite dull. ${ }^{15}$ This is an experience common to the 1910 generation, of which Miłosz was a representative. In pre-war Vilnius, the tragic division of Poland inherent in the interwar period became most fully apparent. Its compact part, ossifying in national orthodoxy, was in conflict with the rest, encompassing everyone with a non-obvious identity. 'It seems to me', said Miłosz in a television interview, 'that the accusations hurled by the national camp at this other nation were correct insofar as any other position easily led to any deviation, from the point of view of Polish patriotism. On the other hand, however, all Polish orthodoxy - adherence to this national camp - had one feature: it was culturally completely idle'. This statement by Miłosz is well complemented by Mieczysław Limanowski's view voiced in 1931: 'Vilnius is the geographical centre of all the lands between the Niemen, the Dnieper, the Dvina, and the Pripyat. This centre is in lethargy today, dying in agony!'16

These features of Miłosz's rebellion were accurately highlighted by Valentina Krupowies: ... not so much Vilnius as a geographic and cultural place, but rather a certain model of Polishness: closed, ethnocentric, focused on its resentments and phobias, frozen in rituals of empty observance, non-intellectual, resigned from scepticism, and although it grew out of the spirit of Romanticism, it was deprived of Romantic irony and thus of self-awareness and distance towards itself. Not provinciality, civilisation, but the dominant ideology. ${ }^{17}$

\section{NOTES ON THE SCANDAL}

The fame of Vilnius was based on innovation. Its Gothic, Renaissance, and Baroque architecture are pioneering phenomena in Eastern Europe. There is one more innovation, the last in the city's history, but best known today', wrote Paweł Jasienica, 'that is

14 T. Venclova, Opisać Wilno, Warsaw, 2006.

15 Cz. Miłosz, 'Do Tomasa Venclovy', [in:] Zaczynając od moich ulic, Wroclaw 1990, p. 35-36.

16 Kurier Wilenski, 1931, No. 6.

17 W. Krupowies, 'Litwa Miłosza, Litwa Konwickiego. Rzecz o polskich zmaganiach z prowincją', Konteksty,

2010, No. 4, p. 99. 
the literary revolution at the beginning of the nineteenth century, an explosion of great poetry, which at first upset even the best brains. In the twentieth century, however, the citizens of the capital of innovation, freed from the guardianship of the tsarist governors, began to show off a variety of conservatism which definitely exceeded the limits of the ridiculousness', he ironically concluded. ${ }^{18}$

Paradoxically, this was a side effect of the freedom regained from the Russian Empire: the nurturing of Polishness in its ossified, degenerated form. Seen from Warsaw's perspective, Vilnius appeared to be a hotbed of backwardness. In Vilnius, independence from Russian Empire meant not so much getting rid of dangers as changing their nature.

The key term for understanding the nature of this conflict is localness, localness versus alienation. This is how Tadeusz Byrski defined it:

Vilnius as a city had one characteristic feature: it had two types of citizens. One was the best known: the broad borderland nature, hospitable, welcoming, and friendly to every person in the world. They understood Vilnius patriotism in the broadest sense and enjoyed everyone who wanted to be there, in the land of Vilnius, and working for that land to increase the value of the Polish estate. The second type of the citizen of Vilnius embraced parochialism, suspicion, aversion to everything that was new, a lack of acceptance for the work of people who were not local; this mysterious term was very broad and, depending on the situation, meant this or that. The newcomers were scrutinised very closely and, interestingly, sometimes a clever impostor, rather than a good specialist, got away with something. ${ }^{19}$

It is only when there is a scandal that it turns out that we are significantly different. The protest of students associated with the Klub Wtóczęów (Vagabonds' Club) against the removal of Ferdinand Bruckner's The Criminals from the repertoire at the Theatre on Pohulanka proved to be a fundamental generational experience. The play turned out to be more than just a shocking novelty in the repertoire. The premiere of The Criminals, directed by Aleksander Zelwerowicz, took place on 29 April 1930. After two performances, the play was cancelled by the mayor of Vilnius. The authorities in Vilnius were outraged by the 'drastic amoral scenes (homosexual love, abortion)'. Zelwerowicz submitted his resignation, which he withdrew a few days later. A performance combined with a debate on the drama was organised. One of the Literary Wednesdays was also devoted to a discussion about The Criminals. The Stowo daily published an open letter to the director Zelwerowicz 'supporting his repertoire policy'. Eventually, The Criminals was cancelled.

On the basis of the unique documents I have found (publications in the press, photographs, and the memories of the participants), I will try to reconstruct these

18 P. Jasienica, Pamiętnik, Warszawa 2007, p. 97.

19 T. Byrski, Wspomnienia. I would like to thank Professor Maria Krzysztof Byrski for providing me with access to Wspomnienia and Professor Maria Prussak for her invaluable assistance. 
events, and, above all, to recall the performance that was to 'introduce cultural Vilnius to a truly modern and European track'.

In Vilnius, after Frank's Karol and Anna, this was the second production of a social drama dealing with the crisis of values and human bonds after the experience of the First World War.

Two months earlier, in February, The Criminals, staged by Leon Schiller and directed by Karol Adwentowicz, was performed in Łódź. The performance was also shown in Warsaw. Antoni Słonimski, who reviewed the play, remarked only on the 'structure' of Bruckner's drama. He complained that the neo-realist drama lacked logic and realism. It must be emphasised that neither the performance in Łódź nor in Warsaw caused a scandal. Zelwerowicz prepared the Vilnius production on the basis of the performance in Łódź.

Bruckner's drama constituted a criticism of the justice system; it primarily questioned the death penalty and showed the corruption of the judiciary system. However, this was not the reason for the protests of the public opinion in Vilnius. It was the drastic nature of the play and two motifs in particular, homosexuality and abortion.

As a result of protests of the press (including the Kurier Wilenski, which was considered democratic), the intervention of Archbishop Jatbrzykowski, the school district superintendent, and the public prosecutor, the mayor of the city cancelled the play after the third show, which was interrupted by the police. Zelwerowicz officially resigned. On 8 May, a special meeting of the theatre committee took place. Under its influence, the governor agreed to one more performance, a private show for invited guests from 'scientific, literary and artistic spheres'.

The discussion, or rather the judgement on The Criminals began on 12 May 1930 just after the performance. The scandal instantly boosted attendance, as reported in the local Dziennik Wileński:

The farce of passing a court judgement over [The Criminals] [...] was a sensation that attracted crowds of spectators. Only the invited were allowed entrance, and only part of them could get inside. According to the calculations of the security authorities, over 2000 people turned up when only 800 could be accommodated in the Teatr Wielki. [...] The mood of the claqueurs, the shouts from the audience, and the applause for clearly anarchistic pieces were the best proof of the moral quagmire into which Mr Zelwerowicz had pushed the Polish theatre in Vilnius, after Reduta. The only profound expert on dramatic literature and a national authority, Professor Pigoń, gave a condemnatory verdict. ${ }^{20}$

A reporter of the progressive Kurier Wileński noted:

A great number of people from the literary, scientific, legal, and medical worlds and two ladies spoke. All of them generally stated that there was absolutely no reason to cancel the play by 
means of a ban as Bruckner's play is not amoral but actually moralistic, with a clear tendency, and includes artistic values. The discussion lasted until $1.35 \mathrm{am}$, in an unusually heated atmosphere. ${ }^{21}$

Reports of the judgment on The Criminals are contradictory. The discussion certainly had a rallying and limited character. That is why it was continued at the Literary Wednesday devoted to the performance. ${ }^{22}$ Witold Hulewicz considered The Criminals to be an artistic work, but it was an isolated voice. Professors Stanisław Pigoń and Stefan Srebrny did not attend the meeting, which was considered a sign of disapproval of Zelwerowicz's production: 'for artistic reasons, the play is not worth talking about that much.' ${ }^{23}$

Eventually, however, the city mayor decided to cancel the play. Zelwerowicz appealed against the decision to the voivode of the Vilnius voivodeship, arguing: The play in question had previously been censored by the relevant authorities of the Republic of Poland and, based on such censorship; it was performed for a longer time in the city of Łódź. Neither in Łódź nor in Vilnius did the prosecuting authorities find the play in conflict with the penal code that upholds social morality and decency. Therefore, formally, the play was given the right to be performed in Poland, and the city of Vilnius should not constitute any exception, standing out formally from the other districts of the country. After all, an article printed in any magazine in Poland and not criticised by the supervisory authorities can be reprinted in any magazine in Vilnius, and for this reason Vilnius magazines cannot be confiscated. ${ }^{24}$

The mayor also wrote to the voivode:

I must stress that the play [The Criminals] was approved by the mayor of Eódź, whose competence does not extend beyond the borders of the city of Łódź and cannot apply to the territory of the city of Vilnius. [...] the decision of the mayor of Vilnius corresponds completely with the opinion of the majority of the intelligentsia of Vilnius. Not approving in the second instance the right decision of the mayor of Vilnius would undoubtedly have a significant impact on lowering the dignity and authority of the administrative authorities. ${ }^{25}$

The governor obviously upheld the decision.

Mackiewicz's Stowo protested against the confiscation. It was the Stowo magazine that published an open letter to Aleksander Zelwerowicz in support of his repertoire policy 'aimed at reviving the cultural life of Vilnius and introducing it to the truly modern and European track. ${ }^{26}$

Among the fifteen signatories of the letter were Czesław Miłosz, Lech Beynar (Paweł Jasienica), Stefan Jędrychowski, Teodor Bujnicki, and Kazimierz Hałaburda.

21 Kurier Wileński, 13 May 1930.

22 The course of this meeting was described in detail by Jagoda Hernik Spalińska, see: J. Hernik Spalińska,

Wileńskie Srody Literackie (1927-1939), Warsaw 1998, p. 120-123.

23 Kurier Wileński, 16 May 1930.

24 LCVA.

25 LCVA.

26 Stowo, 16 May 1930. 
This act of courage turned out to be a fundamental experience: it had community significance and was a remembered lesson on how to experience independence in the world. This 'not-to-be-missed' experience was mentioned several times by Miłosz. Paweł Jasienica's note carries the greatest weight:

I no longer remember who from the Klub Włóczęgów came up with the idea of interfering in the dispute. We sent an unambiguous letter to [Stowo], which was printed eagerly. We condemned the state administration, which had cancelled a play with a social and political edge. Each of the dozen of signatures was accompanied by the address of its author, so that the tyrannical police would know where to look for the culprit. These signatures included the later famous autographs of Teodor Bujnicki, Czesław Miłosz, and Stefan Jędrychowski. [...]

Thus, my public activity began with a protest against the administrative cancellation of Bruckner's [The Criminals]. It will be remarkable if its finale turns out to be a protest lodged two years ago against such a fate of Mickiewicz's [Dziady]. ${ }^{27}$

The scandal with The Criminals became an internal caesura of Alexander Zelwerowicz's management in Vilnius. The second and last season was free from scandals, but also from masterpieces. None of the productions in Vilnius became an artistic event on a national scale, except for The Criminals, although in this case it was the scandal rather than the artistic value of the play performed only twice that made it famous. The conclusion of the story can be drawn from the recollections of Irena and Tadeusz Byrski, who, years later, described the events as follows:

It was a great moral scandal. [...] And there was an outrage; the press protested that it was indecent. Eventually, the censors cancelled the play. In connection with this, there was a huge rally. [...] Now there would be nothing to protest against, but then ... Especially in Vilnius. [...] After all, the city is holier-than-thou. People might not openly say that, but it is a fact. ${ }^{28}$ 
Dr Agnieszka Wójtowicz, a graduate in theatre studies from the Jagiellonian University, a theatre historian, an assistant professor at the Institute of Linguistics at the University of Opole. The author of the monograph Od Orfeusza do Studium o Hamlecie. Teatr 13 Rzędów w Opolu (1959-1964) and Grotowski. Bedeker opolski. The publication of her dissertation, 'Grotowski polityczny', by the Theatre Institute Publishing House in Warsaw is forthcoming in 2021. Her research interests focus on the history of twentieth-century Polish theatre (theatrical activities of Jerzy Grotowski and theatre life in Vilnius in the interwar period). Agnieszka Wójtowicz is the author of over a hundred articles; she has published, among others, in Notatnik Teatralny, Didaskalia, Teatr, and Pamiętnik Teatralny. A co-author of Gra z pamięcia. Jerzy Grotowski w Opolu, the documentary film about Jerzy Grotowski. Selector of the competition for staging early works of Polish literature 'Classics Alive' (Klasyka Żywa), a recipient of the scholarship of the Ministry of Culture and National Heritage (creative scholarship in the category 'Theatre' 2017,2021 ).

Received 6 April 2021

Accepted 27 April 2021

\section{References}

1. Romanowski, A. Mtoda polska wileńska. Kraków: Universitas, 1999.

2. Jankowski, C. Teatry wileńskie. Życie Teatru. 1925. III.

3. Alexandrowicz, M. Dzieje teatru wileńskiego. Wilno: 1938.

4. Venclova, T. Opisać Wilno. Warszawa: Wydawnictwo Zeszytów Literackich, 2006.

5. Miłosz, Cz. Zaczynając od moich ulic. Wrocław: Wydawnictwo Dolnośląskie, 1990.

6. Krupowies, W. Litwa Miłosza, Litwa Konwickiego. Rzecz o polskich zmaganiach z prowincją. Konteksty. 2010. 4: 99-106.

7. Jasienica, P. Pamiętnik. Warszawa: Prószyński, 2007.

8. Byrski, T. Wspomnienia. Rękopis.

9. Hernik Spalińska, J. Wileńskie Środy Literackie (1927-1939). Warszawa: 1998. 
Agnieszka Wójtowicz

„Nusikaltèliai“"Vilniuje

\section{Santrauka}

Ferdinando Brucknerio dramos „Nusikaltèliai“, kurią pastatė režisierius Aleksandras Zelwerowiczius, premjera įvyko Didžiajame teatre Pohuliankos gatvejje Vilniuje $1930 \mathrm{~m}$. balandžio 29 dieną. Tačiau po dviejų vaidinimų, pasipiktinęs „drastiškomis moralinėmis scenomis (homoseksuali meilè, abortas)“, Vilniaus meras spektaklị uždraudè. Zelwerowiczius parašè atsistatydinimo pareiškimą, tačiau po trijų dienų ji atsièmè ir parodè dar vieną spektaklị, sukèlusị diskusijas. Vienas iš „Literatūrinių trečiadienių“ taip pat buvo skirtas „Nusikaltèliams“. Dienraščio Stowo puslapiuose pasirode atviras laiškas režisieriui Zelwerowicziui, kuriame buvo palaikoma jo repertuaro politika. Vis delto spektaklis daugiau nebuvo rodomas. Remiantis unikaliais dokumentais, nuotraukomis, pranešimais spaudoje ir dalyvių prisiminimais, straipsnyje rekonstruojami su šiuo pastatymu susiję ịvykiai. Spektaklis interpretuojamas kaip kūrinys, „vedantis kultūrinị Vilnių i tikrai šiuolaikišką Europą“.

RAKTAŽODŽIAI: Didysis teatras Pohuliankos gatveje, Vilnius, Ferdinand Bruckner, „Nusikaltèliai“, Aleksandr Zelwerovicz, skandalas, cenzūra, Paweł Jasienica 